\title{
LABOUR MARKET FLEXIBILITY IN THE CONTEXT OF THE SHADOW ECONOMY FOR THE CONSTRUCTION INDUSTRY
}

\author{
Andrzej Buszko ${ }^{凶}$ \\ University of Warmia and Mazury in Olsztyn, Poland
}

\begin{abstract}
The article analyses labour market flexibility in the context of the shadow economy. The main research problem is devoted to the flexibility of the construction labour market in relation to the level of labourers who work in a country's shadow economy. The following hypothesis was adopted: Flexibility of the labour market for the construction industry decreases with an increase in the level of the shadow economy. The MIMIC approach was used to calculate the level of the shadow economy in a group of selected countries, divided into three categories. The first category includes countries with a relatively low level of shadow economy (less than $15 \%$ of their GDP). The second group contains a level starting from 15 to $25 \%$ of their GDP, while the third group has a shadow economy that exceeds $25 \%$ of GDP. The Pearson correlation index was applied in order to measure the coefficient level between market flexibility and the size of the shadow economy. The flexibility of the labour market was calculated as the change of unemployment caused by the change of construction industry output. The research proved that the correlation between market flexibility and the shadow economy is significant. This is due to the fact that the Pearson index reached the level of 0.866 , which means that whenever the shadow economy increases, the labour market flexibility of the construction industry decreases.
\end{abstract}

Key words: shadow economy, market flexibility, price setting, equilibrium, labour market, construction industry

JEL codes: O17, H26, C39, K42, J22

\section{INTRODUCTION}

Markets are believed to be more flexible than other economic categories, although the meaning of flexibility remains imprecise. For mainstream academics, researchers and economists, market flexibility is considered from a quite narrow perspective - as price changes in market equilibrium. Such assumptions are typically discussed from two approaches: price setting and price adjustment, especially from allocation strategy. But in the wider approach, market flexibility can be understood as the effectiveness of allocation from both a macro- and microeconomic perspective toward goal achievement. It is common knowledge that some markets are more flexible than others even though they are influenced by the same factors. Arguments about supply and demand elasticity pertain to the ideal case of perfectly competitive markets, which assumes aggregate supply and demand curves with many sellers and buyers who are price checkers and who trade by price alone. Discussion of flexible and rigid prices, as is habitual in neoclassical theories, gives a false impression that prices are either variable or static. Moreover, they often remain stable and cannot be changed, although strong impacts can be foreseen. Such phenomena is explained in many ways. 
Distinctive clarifications are generally based on the structure of the market, the level of development and social egalitarianism. During the business cycle, market prices are expected to move procyclically [Jackson 2015]. Whenever there are fewer administrative prices the market appears to be more inflexible. Such prices are controlled by government authorities and any change requires official approval.

Contradictory situations appear whenever there is an unrestricted market with uncluttered price competition. However, such justifications are often unsatisfactory. This is because market flexibility can change unexpectedly and can rapidly break all known economic rules and formulas. Such occurrences are being noticed more and more often. In some markets, flexibility plays a crucial role. For example, this is a key factor fostering electricity market. This market needs flexibility in order to cope with the uncertainty associated with large-scale intermittent resource penetration [Goutte and Vassilopoulos 2019]. Flexibility is applied in construction as well. During pandemic time (the case of crown virus) higher number of hospitals are needed in a relatively very short time. Chinese construction companies could provide a hospital on turn-key basis within 14-day time. It is a good example of market adaptability. However, from the other hand agility is not a typical idea, which can be proceeded by market agents, especially from supply and demand perspective. Such mould is applied on different markets [Villar et al. 2018]. In market-oriented economies there is characteristic steady tension on firms to adopt themselves to changing market environment. If they are agile, finally they are coined "flexible firms". This refers to types of organisational forms that enable employers to achieve required flexibility in order to maintain their competitiveness in the market [Bilic 2017].

The term "flexibility" came to economy from physics. It has Latin roots and can be translated from flexus as the ability to bend, wind or bow without losing structure and remain unbroken. In economics, the idea of flexibility is generally discussed as the level and speed of changes influenced by selected factors. Such an approach is typical in orthodox economy; for example, whenever flexibility of production is being deliberated and the focus is changes in the manner of production based upon market forces. When the needs of the market require modifications in production, and if those modifications appear quickly and substantially, the market appears to be flexible. If not, the market appears to be stable or firm.

According to neoclassical approaches, price movements induce market responses, which can be documented by supply and demand curves. The market is regarded to be very flexible whenever a small change in prices reaches quick market equilibrium, as opposed to when even big changes in price cannot push market fluctuations and adjustments become difficult. Deviation from expected market adjustments was noted from the early beginnings of economic analysis, but was commonly explained by unfair competition. Even though such an explanation is widespread and often accepted, it is not thorough enough - there are crucial doubts and questions referring to the roots of unfair competition and its mechanism in a market-oriented economy. What factors foster unfair competition? Why is unfair competition (at least in some markets) allowed to develop? What is the real framework of unfair competition? This is why orthodox neoclassical economics cannot explain virtual price adjustments of the market. Market equilibrium is the result of many individuals taking part in economic performance. Those individuals come from different parts of the market, represent different strategies and search for different goals.

Additionally, orthodox neoclassical economists prefer to analyse market flexibility from a static perspective. This leads to very theoretical models of assumption that are quite removed from real market performance, especially nowadays when changes are so rapid, very frequent and their effects seem to be very contradictory. Moreover, some companies have much stronger market influence than the others. In such cases, their impact on market flexibility is more visible than it is for others. Moreover, their strategy should be taken into account, as well - if they wish to retain market flexibility on a certain level, they are able to do so more effectively than other companies. Such a situation should be discussed not only during mergers and acquisitions, or when companies take over projects, but also, for example, tax optimization.

Economics theory needs to clarify the present situation in more realistic way, providing not only solutions but also creating more truthful mechanisms of market 
performance. Orthodox neoclassical economy relies on too many convenient assumptions which overly simplify the explanation of market flexibility. This is especially apparent with investment flexibility, which is defined as a firm's ability to adjust the amount of capital investment in response to its current or projected profitability. Managerial freedom to adjust existing operations enhances equity value, because when managers have such freedom, they can capitalize on favourable investment opportunities and limit losses from adverse market conditions as new information arrives [Myers 1977]. Upon developing such an assumption, the question on the limits of market freedom and emerging investment opportunities should be answered. If the market is affected by any limits, the discussion should focus on the impact on market freedom and investment opportunities. Whenever this impact becomes robust, market freedom starts to be imperfect, thus reducing market flexibility significantly. Greater economic freedom reduces friction and allows a firm to exercise these investment options; such freedom can enhance the firm's future investment in response to current profitability (investment flexibility) and the degree of convexity of equity value with profitability [Chen et al. 2015].

\section{THE METHODOLOGICAL ASSUMPTION}

The main goal of the research is to indicate the changes in flexibility of the labour market for the construction industry resulting from the size of a country's shadow economy. The level of the shadow economy was measured by MIMIC approach. In this respect, the following data were taken into an account: unemployment rate, criminality rate, number of VAT payers, the share of construction in GDP. Such data are very useful in explaining the level of the shadow economy in any country due to several assumptions. One is that a high rate of criminality enlarges the shadow economy. Since VAT affects the final price of products, VAT payers try to avoid such taxation. The unemployed seek any source of earnings, so activity in the shadow economy might be source of engagement. Among all industries, the construction industry is most likely to perform in the shadow economy framework [Rusche and Kirchheimer 1939, Warren and McManus 2007, Kindsfaterienè and Lukaševičius 2008, Goel and Nelson 2016].

In calculation the MIMIC model becomes a multi regression function. Structural parameters are appraised with commanding restraints on the coefficient matrix and the covariance matrix of error. All data used in equations were appraised by a likelihood procedure, taking the reduced form into consideration and not imposing any restrictions on the variance-covariance matrix. Statistica software was applied to calculate (based on MIMIC approach) the level of the shadow economy among selected countries. Analysed countries were divided into three categories.

The first category includes those countries where the level of the shadow economy is relatively low (less than $15 \%$ of GDP) and is generally assumed that it does not disturb market performance. The second category refers to those countries where the shadow economy operates at a higher level - from 15 to $25 \%$ of GDP, and the third group of countries consists of those where the level of the shadow economy is higher and its impact on the national economy is believed to be quite significant. Based upon such assumptions, the following countries were taken into an account:

- Category 1: Iceland, Switzerland, Austria, Finland, Norway, Sweden, Denmark;

- Category 2: Estonia, Latvia, Lithuania, Czechia, Poland, Slovakia, Portugal;

- Category 3: Greece, Slovenia, Italy, Croatia, Serbia, Romania, Bulgaria, Spain, Russia.

The flexibility of the construction market was calculated as the change of unemployment caused by the change of construction industry output. The following formula is applied:

$$
\begin{gathered}
\text { flexibility } \\
\text { of the market }(\%)
\end{gathered}=\left|\frac{\Delta \text { unemployment change }(\%)}{\Delta \text { construction output }(\%)}\right|
$$

The research was conducted for the years 2015-2018 . The change of unemployment rate and construction industry output was calculated as the difference between the year 2018 and 2015. The shadow economy level was calculated as an average result for 2015, 2016, 2017 and 2018. Then the Pearson correlation index was applied in order to measure the coefficient level between the market flexibility and the size of the shadow economy. 
Data was used from the OECD Statistical Compendium, Economic Outlook Statistics and Projections, OECD Standardised National Accounts, OECD Labour Force Statistics and National Statistics of Statistical Offices representing the group of selected countries.

The following hypothesis was taken: Flexibility of the labour market for the construction industry lowers with the increase of the shadow economy level.

\section{THE SHADOW ECONOMY IMPACT ON MARKET PERFORMANCE}

At the same time when legal economic activity started, the shadow economy also appeared [Buszko 2019]. Shadow and legal economies perform together and they can be regarded as substantive for each other. Loayza [1996] points out that whenever the shadow economy increases the same time the legal economy is reduced. The roots and of the shadow economy are recognised and remain vital even up till now. But the motion of it supposed to be researched since lot of changeable factors fostering shadow economy activity. The roots of shadow economy are generally associated with:

1. The taxation system. Whenever taxes are higher the level of shadow economy increases [Krstić and Schneider 2015].

2. The complicated and contradicted law system [Ainsworth 2011].

3. High level of corruption supports shadow economy development [Choi and Thum 2003].

4. Organised crime is closely linked with illegal activity including shadow economy performance [Dabla-Norris and Feltenstein 2003].

5. Cultural implications [Alm and Torgler 2006].

6. The quality of institutional solutions [Laruelle 2008].

The shadow economy is studied from many perspectives like: history, psychology, anthropology, law, cultural aspects, sociology and - very importantly - economy. Albeit the legal and shadow economies perform parallely, they usually infiltrate each other. It could even be stated that they depend on each other. The shadow economy is devided into different categories like grey economy, black, evel white immoral one. Nevertheless, a lot numerous cases are related to undeclared employment. This happens when managers or owners of the companies do not officially hire workers. They are paid due to the oral agreement only. Such practice is very common in construction industry, especially. This is because in this sector different skills are required, starting from relatively quite simple jobs to very complicated ones, based on well prepared, educated staff. The last category of employees generally require written agreement, but sometimes the official salary is not so high since the rest of money is paid unofficially [Bajada and Schneider 2005].

Taking such an assumption into consideration, it is worth highlighting that the shadow economy is a very important economic category which must be explored. Schneider estimates the size of the shadow economy in 2005 to range from $7.9 \%$ of official GDP in the United States to $66.4 \%$ in Georgia. On average, shadow economic activities amount to $15 \%$ of official GDP in Organization for Economic Cooperation and Development (OECD) countries, while the average size in other parts of the world is around 35\%. The shadow economy proved to be very dangerous, especially in developing countries. This is due to the fact that it supports budget deficit (fiscal capacities becomes inefficient) and there is less money for needed redistribution. Such situation happens not only in Greece (where shadow economy constitutes nearly $30 \%$ of GDP of this country and has negative impact on taxation and security system) but in Spain, Italy and Portugal as well. Greek debt crisis, which started in 2010, showed all negative consequences of shadow economy performance [Buehn et al. 2013].

Even though considerable literature exists on different aspects of the shadow economy there is still a lack of a common (widely accepted) definition of the shadow economy. Buehn et al. [2013] suggest to implement description that shadow economy consists of all market activity, which is deliberately hidden from public authorities to avoid income payment obligations. Moreover shadow economy affects working standards - making them worse - like decreasing wages, safety and violating nearly all administrative procedures.

Furthermore, shadow economy makes inappropriate international competitiveness. Those countries with high level of shadow economy do not obey any rules and depraving the market regulation. Quite often, the 
offered products or services are manufactured without any standards and final quality become very poor one. In addition, the shadow economy favours corruption and depress the confidence in institutions, finally citizens are generally very disappointed and annoyed [Barbosa et al. 2013].

Various authors point out particular positive aspects of the shadow economy. Some individuals may find a job over there, otherwise they will remain jobless. Even for a long time. It should be noticed that unemployed need government support. Working in the framework of shadow economy one can improve its financial standing. Government care is less needed. Part time activity (even illegal one) can add a dynamic element to the economy and increase competition in some sectors, and can improve income distribution in society [Smith 2002].

Whenever company faces problem with its financial standing it is more likely to perform in the shadow economy. Effective law and appropriate penalties my discourage potential applicants. Enterprises which are sued are less (or practically not) willingly to conduct themselves illegally. At the same time, companies may expect some superfluous protection due to the discriminating sanctions set down by corrupted officials. Another situation is also workable. If companies operating in the shadow economy frameworks found out that fines or other restrictions are merciful ones, they would remain incentive to carry out their business over there. They would not switch into legal sphere of economy [Andrews et al. 2011]. Although substantial literature on various shadow economy aspects exists there are seldom studies focused on the relation between market flexibility and the shadow economy.

\section{THE SPECIFICS OF THE CONSTRUCTION INDUSTRY IN THE CONTEXT OF ILLEGAL EMPLOYMENT}

The construction industry is always regarded to be as the pillar of national economy. This is because construction improves urban and rural infrastructure very much, strengthens urbanization process and improves business efficiency [Sharma and Sehgal 2010]. The construction industry constitutes important share of national GDP (accounting from 3 to $10 \%$ ). Additionally creates significant employment opportunity and implements important government investment projects. In another sense, the products of the construction industry are investment or capital goods, for their value is high in relation to the income of the purchaser [Hillebrandt 1985]. There is no doubt that the construction sector plays a vital role in an individual's well-being in terms of the live conditions and suitable infrastructure [Durdyev et al. 2017].

Construction is known as labour intensive industry that why it requires not only more labour force but employees of various skills. For this reason in many countries, the labour demand in construction sectors is supplied by rural surpluses. Such situation was noticed not only in less developed countries but in India and China as well [Sharma and Sehgal 2010]. Working on construction site even less skilled employees can be useful by completing simple tasks. They are paid relatively modest. Additionally to that, they can learn more because of assisting better or the best skilled workers. Managerial posts are occupied by well-educated and trained people. In this way, practically each person can find a job in construction sector [Kirubaashini 2015]. This feature makes good space for shadow economy activity, mainly because of three very important issues:

- cost saving operations;

- possibility to get some money in the form of part-time work;

- even during recession, illegal employment plays as the "safe pillow" for unemployed workers.

Referring to the first issue, all social benefits and taxes are excluded, so the final price offer for investors may be very attractive. In this way, a construction company can achieve competitive advantage. The shadow economy can be considered as a chance for part-time workers to earn some additional money. This is mainly due to the fact that in the construction industry, any person - even without any skills - can get work. Earned in this way, money (at least part of it) can be spent in the legal economy. If the VAT is paid so paradoxically, one can say that illegal employment can support national budget revenue. During a recession, illegal employment in the framework of the shadow economy is the only choice for workers to be paid any money. In this manner they can survive, especially in those countries where government social assistance is not well 
Buszko, A. (2020). Labour market flexibility in the context of the shadow economy for the construction industry. Acta Sci. Pol. Oeconomia 19 (4), 23-32, DOI: 10.22630/ASPE.2020.19.4.37

developed. This is one reason that legal authorities are often not so keen to reduce not only illegal employment, but the size of the shadow economy as a whole.

\section{FINDINGS AND DISCUSSION}

The level of the shadow economy among selected countries vary significantly (Table 1). The highest level was noticed in Russia and Greece, $35 \%$ and $32 \%$ of their GDP, respectively. The lowest was observed in Scandinavian countries. The shadow economy in Russia has a long history and generally is accepted by the nation. It has different aspects, but nowadays organised crime and corruption have the most dangerous impact fostering shadow economy development in Russia [Pomeranz 2010]. However, in Greece, the shadow

Table 1. Change of construction industry output and unemployment rate in context of shadow economy level in 2015-2018

\begin{tabular}{|c|c|c|c|c|}
\hline \multirow[t]{2}{*}{ Country } & $\begin{array}{c}\text { The change of industry } \\
\text { output }\end{array}$ & $\begin{array}{l}\text { The change } \\
\text { of unemployment }\end{array}$ & $\begin{array}{l}\text { The size of shadow } \\
\text { economy as \% GDP }\end{array}$ & $\begin{array}{l}\text { Flexibility } \\
\text { of the market }\end{array}$ \\
\hline & \multicolumn{4}{|c|}{$\%$} \\
\hline Iceland & 2.00 & 4.00 & 8.00 & 2.00 \\
\hline Switzerland & 2.00 & 3.00 & 10.00 & 1.50 \\
\hline Austria & 2.00 & 4.00 & 9.00 & 2.00 \\
\hline Finland & 3.00 & 4.00 & 12.00 & 1.34 \\
\hline Norway & 3.00 & 4.00 & 12.00 & 1.34 \\
\hline Sweden & 2.00 & 4.00 & 12.00 & 1.34 \\
\hline Denmark & 2.00 & 3.00 & 12.00 & 1.34 \\
\hline Estonia & 3.00 & 2.00 & 21.00 & 0.67 \\
\hline Latvia & 2.00 & 1.00 & 24.00 & 0.50 \\
\hline Lithuania & 4.00 & 1.00 & 25.00 & 0.25 \\
\hline Czechia & 4.00 & 2.00 & 24.00 & 0.50 \\
\hline Poland & 4.00 & 2.00 & 25.00 & 0.50 \\
\hline Slovakia & 4.00 & 2.00 & 25.00 & 0.50 \\
\hline Portugal & 3.00 & 1.00 & 25.00 & 0.34 \\
\hline Greece & 2.00 & 0.20 & 32.00 & 0.10 \\
\hline Slovenia & 2.00 & 1.00 & 30.00 & 0.50 \\
\hline Italy & 3.00 & 1.00 & 29.00 & 0.34 \\
\hline Croatia & 3.00 & 1.00 & 29.00 & 0.34 \\
\hline Serbia & 2.00 & 1.00 & 28.00 & 0.50 \\
\hline Romania & 3.00 & 2.00 & 27.00 & 0.67 \\
\hline Bulgaria & 3.00 & 1.00 & 31.00 & 0.34 \\
\hline Spain & 2.00 & 1.00 & 28.00 & 0.50 \\
\hline Russia & 4.00 & 0.50 & 35.00 & 0.12 \\
\hline
\end{tabular}

Source: Author's own calculation based on data from OECD Statistical Compendium, Economic Outlook Statistics and Projections, OECD Standardised National Accounts, OECD Labour Force Statistics and National Statistics of Statistical Offices representing the group of selected countries. The size of shadow economy was calculated based on MIMIC approach presented in methodological approach. 
economy is not only affected by history but mainly by long-lasting economic crisis, and its performance is included in official statistics. This was done because authorities wanted to statistically reduce the debt and get official acceptance for further money borrowing [Aristidis and Ioannis 2014]. In Scandinavian countries the low level of the shadow economy is explained by a sound market-oriented economy and strong democratic movement, thus limiting the space for shadow economy development. In Central European Countries the level of the shadow economy is relatively high, but during recent years its level has been decreasing. The same process has been perceived in Baltic states like Estonia, Latvia and Lithuania. Spain, Portugal and Italy face some problems with high rates of unemployment, especially among the younger population. This factor fosters shadow economy development. Additionally, their economies have lowered and their standard of living has worsened. That is why the shadow economy is regarded as an alternative source of income.

The market flexibility differs in selected countries. The highest level was recognised in well developed countries, the lowest level in countries still under transformation and with economic problems like Russia, Greece and the Balkan region. The low market flexibility scoring should be taken into an account even in Italy, Spain and Portugal. This is because the efficiency of proposed reforms might be not successful. Attention grabbing is the score of Pearson correlation index between market flexibility and the shadow economy.

The coefficient level between market flexibility and the shadow economy is significant and it is calculated at 0.866 (Table 2). This means that whenever the shadow economy grows, market flexibility decreases. Such a result has important influence not only on market performance, both on macro- and microeconomic levels, but on the effectiveness of any activity as well. It is important to underline that there are two economies: legal and shadow. Depending on their sizes, market flexibility varies. When the level of the shadow economy increases, the market flexibility becomes rigid. In this way, two economic occurrences can be explained: the low efficiency of reforms (in those countries where the shadow economy plays an important role) and the appearance of unexpected market situations.

At least some economic reforms are bad executed since they start from misleading assumptions, and decisions makers do not take into an account the role of the shadow economy in the context of market flexibility [Bresser-Pereira 1993]. Ignoring such a role of the shadow economy and market flexibility, this has been the cause of higher costs of reforms, especially in those countries where transformation was introduced. From economy perspective spending's supposed to be associated with action and effects. Moreover, new rules and solutions are provided. It is important not to make steps without taking efficiency into consideration. Obviously investment-designed logic is applicable, so there is a need to establish unique form of methodological motion. Such an approach is not so easy and created system, even logical one is limited to available resources constrains [Sukharev 2015].

An unexpected situation showing the influence of the shadow economy can be seen when there is a higher level of budget revenues, even though a recession is observed. This is because money from the shadow economy is spent in an official way and VAT supports the national budget. Referring to the theory originally presented by Hayek, who stressed the role of prices as the purest and most important source of

Table 2. The value of correlation between market flexibility and size of the shadow economy

\begin{tabular}{lcc}
\hline Category & Market flexibility & Shadow economy \\
\hline Market flexibility & - & -0.866 \\
\hline Shadow economy & -0.866 & - \\
\hline$p<0.05$. & & \\
Source: Author's own calculation based on Table 1 data.
\end{tabular}



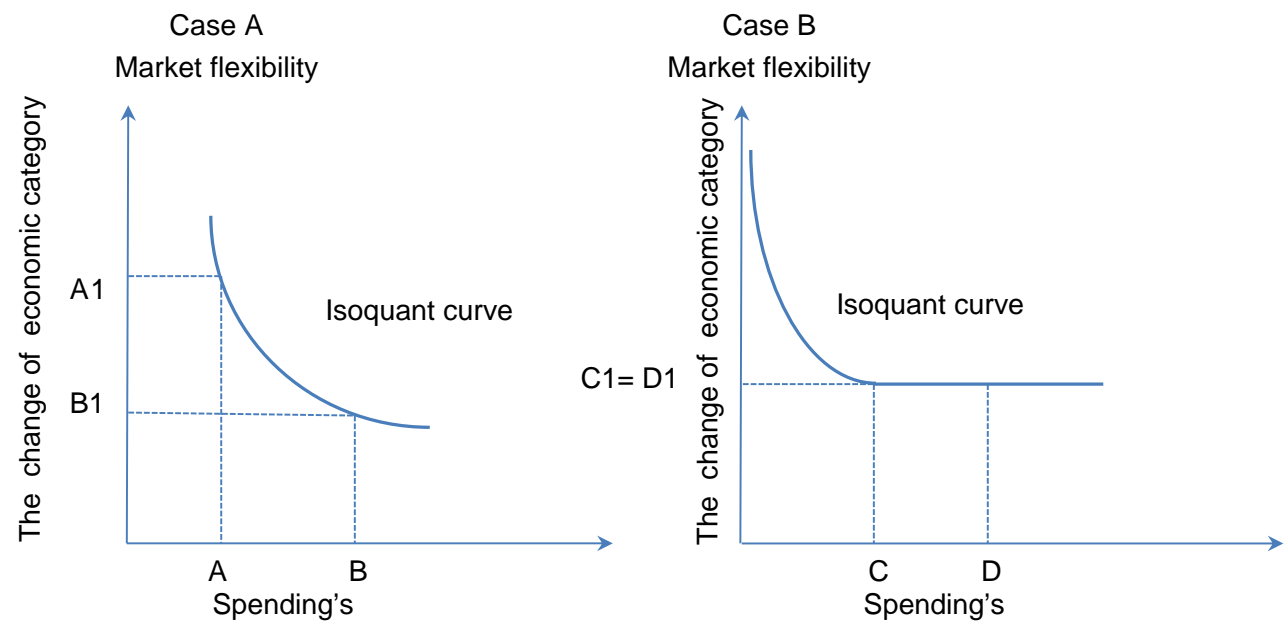

Fig. Market flexibility based upon shadow economy size Source: Author's own elaboration.

information on economy and market performance, such an approach may be applied in the shadow economy in the context of capital allocation. Freely and unlimited prices no matter the wholesale or retail ones are articulated by wages, interest rates, foreign currency cross-rates, quantifiable opportunity, transaction costs and many other forms, are the most important signals looming out in a healthy economy [Hayek 1945, Roberts 2010]. A discussion summary is presented in the figure.

Case A is applied to those countries with a low level of shadow economy and Case B to those with a high level of shadow economy. In the first situation, the isoquant curve is regular and demonstrates the changes between spending and market flexibility. Although the shadow economy affects market flexibility, some positives results can be achieved. The situation changes intensely in Case B. Even though spending grows, there are no changes in the market flexibility - it has become rigid.

\section{CONCLUSIONS}

Based upon the research results it can be stated that the hypothesis has been accepted. Firstly, the shadow economy is associated with the market flexibility. Whenever a high level of shadow economy is observed, the market flexibility lowers, and finally is converted to an unchanging position. In this way a new outlook on market performance, including its equilibrium, must be taken into an account. If this result is applied to industries other than construction, a change in the traditional approach to market flexibility will be required. Secondly, another scope of exploration can be suggested, connected with the efficiency of reforms in consideration of the shadow economy level. Even though that shadow economy can exist separately from legal activity, its performance will occur in lawful motion. Thirdly, the shadow economy can explain market paradoxes, which are very hard to be clarified with neoclassical economic theory. This theory has quite lot of supporters but should refer also to other economic categories such as the shadow economy, since market performance will be not only more detailed but more correctly described, as well.

\section{REFERENCES}

Ainsworth, R.T. (2011). VAT fraud as a policy stimulus - is the US watching? VAT withholding VAT, RTvat, and the Mittler Model. Boston Univeristy School of Law Working Paper 11-08.

Alm, J., Torgler, B. (2006). Culture differences and tax morale in the United States and in Europe. Journal of Economic Psychology, 27 (2), 224-246.

Andrews, D., Caldera Sánchez, A., Johansson, Å. (2011). Towards a better understanding of the informal economy. OECD Economics Department Working Papers 873. https://doi.org/10.1787/18151973 
Aristidis, B., Ioannis, M. (2014). The absorption of a shadow economy in the Greek GDP. Procedia Economics and Finance, 9, 32-41.

Bajada, C., Schneider, F. (Eds.) (2005). Size, causes and consequences of the underground economy: an international perspective. Ashgate, Aldershot.

Barbosa, E., Pereira, S., Brandăo, E. (2013). The Shadow Economy in Portugal: An Analysis Using the MIMIC Model. FEP Working Papers 54.

Bilic, A. (2017). Flexicurity - way out or way with traps and hurdles? [In:] Z. Radic, A. Roncevic, L. Yongqian (Eds.), Economic and Social Development. 22nd International Scientific Conference on Economic and Social Development "Legal Challenges of Modern World". Book of Proceedings. Varazdin Development and Entrepreneurship Agency, Varazdin, 24-35 [online edition].

Bresser-Pereira, L. (1993). Economic reforms and economic growth: efficiency and politics in Latin America. Penguin, London.

Buehn, A., Lessmann, Ch., Markwardt, G. (2013). Decentralization and the shadow economy: Oates meets Allingham-Sandmo. Applied Economics, 45 (18), 2567-2578.

Buszko, A. (2019). Kulturowe uwarunkowania powstawania i funkcjonowania szarej strefy. Wydawnictwo Uniwersytetu Warmińsko-Mazurskiego w Olsztynie, Olsztyn.

Chen, C.Y., Chen, P., Jin, Q. (2015). Economic Freedom, Investment Flexibility, and Equity Value: A Cross-Country Study. The Accounting Review, 90 (5), 1839-1870.

Choi, P.J., Thum, M. (2003). The dynamics of corruption with the ratchet effect. Journal of Public Economics, 87 (3-4), 427-443.

Dabla-Norris, E., Feltenstein, A. (2003). An analysis of the underground economy and its economic consequences. International Monetary Fund Working Paper WP/03/23.

Durdyev, S., Omarov, M., Ismail, S. (2017). Causes of delay in residential construction projects in Cambodia. Cogent Engineering, 4 (1), 1291117. https://doi.org/10.1080/23 311916.2017 .1291117

Goel, R.K., Nelson, M.A. (2016). Shining a light on the shadows: Identifying robust determinants of the shadow economy. Economic Modelling, 58 (C), 351-364.

Goutte, S., Vassilopoulos, P. (2019). The value of flexibility in power markets. Energy Policy, 125 (C), 347-357.

Hayek, F. (1945). The Use of Knowledge in Society. American Economic Review, 35 (4), 519-530.

Hillebrandt, P. (1985). Economic Theory and the Construction Industry. Palgrave Macmillan, London.

Jackson, W.A. (2015). Markets and the Meaning of Flexibility. Economic, 20, Part 2, 45-65.
Kindsfaterienè, K., Lukaševičius, K. (2008). The Impact of the Tax System on Business Environment. Inzinerine Ekonomika - Engineering Economics, 57 (2), 70-77.

Kirubaashini, D. (2015). Role of E-HRM in achieving HRM performance in construction firms in Singapore. BSc study. National University of Singapore, Singapore [manuscript].

Krstić, G., Schneider, F. (2015). Formalizing the Shadow Economy in Serbia. Policy Measures and Growth Effects. Springer, Cham - Heidelberg - New York Dordrecht - London.

Laruelle, M. (2008). The concept of ethnogenesis in Central Asia: political context and institutional mediators (1940-50). Kritika: Explorations in Russian and Eurasian History, 9 (1), 169-188.

Loayza, N.V. (1996). The economics of the informal sector: a simple model and some empirical evidence from Latin America. Carnegie-Rochester Conference Series on Public Policy, 45, 129-162.

Myers, S.C. (1977). Determinants of corporate borrowing. Journal of Financial Economics, 5 (2), 147-175.

OECD Economic Outlook: Statistics and Projections [dataset archive]. https://doi.org/10.1787/eo-data-en

OECD Labour Force Statistics [dataset archive]. https://doi. org/10.1787/23083387

OECD Standardised National Accounts [dataset archive]. Retrieved from http://www.oecd.org/sdd/na [accessed 23.01.2019].

OECD Statistical Compendium [dataset archive]. Retrieved from https://now.allthatstats.com/sources/oecd/ROOT [accessed 12.12.2018].

Pomerantz, W.E. (2010). Legal Reform Through the Eyes of Russia's Leading Jurists. The Vlast Debate on the Russian Judiciary. Problems of Post-Communism, 57 (3), 3-10.

Roberts, J.M. (2010). Access to Information: Vital for Efficient Markets and Economic Reform. [In:] T. Miller et al. (Eds.), 2010 Index of Economic Freedom. The Heritage Foundation and Dow Jones \& Company, Washington, DC - New York, NY, 43-55.

Rusche, G., Kirchheimer, O. (1939). Punishment and Social Structure. Russell and Russell, New York, NY.

Sharma, C., Sehgal, S. (2010). Impact of infrastructure on output productivity and efficiency. Indian Growth Development Review, 3 (2), 100-121.

Smith, R.S. (2002). The underground economy: Guidance for policy makers? Canadian Tax Journal - Revue Fiscale Canadienne, 50 (5), 1655-1660.

Sukharev, O. (2015). Institutional Theory of Economic Reforms: Basic Imperatives. Ecoforum, 4, 2 (7), 8-25. 
Villar, J., Bessa, R., Matos, M. (2018). Flexibility products and markets: Literature review. Electric Power Systems Research, 154, 329-340.
Warren, N., McManus, J. (2007). The impact of tax gap on future tax reforms. Australian Economic Review, 40 (2), 200-207.

\section{ELASTYCZNOŚĆ RYNKU PRACY W KONTEKŚCIE SZAREJ STREFY}

\section{STRESZCZENIE}

Artykuł poświęcono elastyczności rynkowej w kontekście szarej strefy. Główny problem badawczy dotyczy elastyczności budowlanego rynku pracy w odniesieniu do poziomu szarej strefy. W badaniach przyjęto następującą hipotezę: Elastyczność budowalnego rynku pracy spada, kiedy wzrasta poziom szarej strefy. W badaniach wykorzystano narzędzie MIMIC do ustalenia poziomu szarej strefy w wybranych krajach. Podzielono je na trzy kategorie. W pierwszej grupie ujęto te, w których poziom szarej strefy był niższy od $15 \%$ PKB, w drugiej te, w których poziom szarej strefy waha się od 15 do $25 \%$ PKB, a w trzeciej te, w których szara strefa jest na poziomie wyższym od 25\% PKB. Posłużono się także współczynnikiem korelacji Pearsona w celu ustalenia związku między elastycznością rynku pracy a poziomem szarej strefy. Elastyczność rynku pracy została zmierzona zmianą poziomu bezrobocia wynikającą ze wzrostu produkcji budowlano-montażowej w analizowanych krajach. Na podstawie przeprowadzonego badania stwierdzono silną korelację ujemną $(0,866)$ między szarą strefą a elastycznością budowalnego rynku pracy. To oznacza sytuację, w której elastyczność budowlanego rynku pracy maleje wraz ze wzrostem poziomu szarej strefy.

Słowa kluczowe: szara strefa, elastyczność rynku, kształtowanie ceny, równowaga, rynek pracy, budownictwo 